\title{
ANALISA KONTRAK PROYEK KONSTRUKSI DI INDONESIA
}

\author{
Johan Oberlyn Simanjuntak ${ }^{1)}$, Bartholomeus ${ }^{2)}$, \\ Salomo Simanjuntak ${ }^{3)}$, Partahi Lumbangaol ${ }^{4)}$, Astri Agnes ${ }^{5)}$ \\ Fakultas Teknik Universitas HKBP Nommensen, Medan \\ Email: oberlyn.simanjuntak@yahoo.co.id ${ }^{1)}$, saragih_27@yahoo.com ${ }^{2)}$, \\ simanjuntak679@yahoo.co.id ${ }^{3)}$, partahi@yahoo.com ${ }^{4)}$, astriagnes889@gmail.com ${ }^{5)}$
}

\begin{abstract}
The contract is a very importand document in the project. Contract are seen as laws that must be obeyed, govern and control the rights and obligations between service users and service providers in the project. In world of construction in Indonesia, the standard used for contract documents must be based on Law No.2 of 2017 on construction services as a guide and guidance in constructions activities in Indonesia. In the international world, FIDIC documents has long been recognized, which is a contractual rule that has been used by many countries. FIDIC has also been widely adapted to government and private projects in Indonesia. The first analysis is to identify the contract documents used in several project in North Sumatera region. This analysis shows that the FIDIC red book document is the most suitable document to be used in several project in North Sumatera. The second analysis is comparing the FIDIC document and the analysis shows that the contract document that best matches the points in the questionnaired is Law No. 2 of 2017 on construction services. From the analysis of the previous discussion a conclusion was drawn regarding the philosophy of the work contract discussed was the type of unit price contract based on.
\end{abstract}

\section{Keywords : Contract, FIDIC, Law No.2 of 2017 on Construction Service}

\begin{abstract}
Abstrak
Kontrak merupakan dokumen yang sangat penting dalam proyek. Kontrak dipandang sebagai hukum yang harus dipatuhi dan menjadi pengatur serta pengendali hak-hak dan kewajiban antara pengguna jasa dan penyedia jasa dalam proyek. Dalam dunia konstruksi di Indonesia, standar yang digunakan untuk dokumen kontrak harus berdasarkan pada Undang-Undang No. 2 Tahun 2017 tentang jasa konstruksi sebagai panduan dan pediman dalam kegiatan konstruksi di Indonesia. Di dunia internasional sudah lama dikenal dokumen FIDIC yang merupakan aturan kontrak yang telah digunakan banyak negara. FIDIC juga banyak diadaptasi pada proyek-proyek pemerintah maupun swasta di Indonesia. Analisa yang dilakukan pertama yaitu mengindentifikasi dokumen kontrak yang digunakan di beberapa proyek di wilayah Sumatera Utara. Analisa tersebut menunjukkan bahwa dokumen FIDIC Red Book merupakan dokumen yang paling sesuai digunakan di beberapa proyek di Sumatera Utara. Analisa kedua yaitu membandingkan antara dokumen FIDIC dan Undang-Undang No.2 tahun 2017. Analisa tersebut menunjukkan bahwa dokumen kontrak yang paling sesuai dengan poin-poin yang ada pada kuisioner yaitu dokumen Menteri Pekerjaan Umum. Dari pembahan sebelumya disimpulkan bahwa pedoman kontrak yang digunakan di Indonesia khususnya proyek yang ada di Sumatera yaitu masih mengacu pada Undang-Undang No.2 tahun 2017 dan menggunakan jenis kontrak Unit Price.
\end{abstract}

Kata kunci : Kontrak, FIDIC, Undang-Undang No.2 tahun 2017 tentang Jasa Konstruksi 


\section{PENDAHULUAN}

Undang-Undang No.2 Tahun $2017^{3}$ tentang Jasa Konstruksi pasal 1 ayat 8 menyatakan bahwa kontrak kerja konstruksi adalah keseluruhan dokumen kontrak yang mengatur hubungan hukum antara pengguna jasa dan penyedia jasa dalam penyelenggaraan jasa konstruksi. Kontrak kerja konstruksi merupakan salah satu hal yang paling krusial dalam proses kerja sama dalam pekerjaan konstruksi. Segala hak dan kewajiban dalam kontrak disusun menjadi suatu perjanjian tertulis antara pengguna ke penyedia jasa.

Prinsip utama dalam pembuatan dan penyusunan kontrak konstruksi haruslah berpijak pada kesetaraan dan kejelasan. Setara maksudnya adalah bahwa para pihak yang berkontrak memiliki status dan kepentingan yang sama. Tujuan utama dibuatnya sebuah kontrak konstruksi tentu agar kesepakatan yang dibuat kedua belah pihak saling mengikat secara hukum.

Dalam pelaksanan pekerjaan konstruksi terdapat berbagai jenis kontrak berdasarkan ketentuan Kementerian Pekerjaan Umum dan Perumahan Rakyat RI, mengutip sistem kontrak luar negeri seperti FIDIC (Federation Internasional Des Ingenieurs-Conseils), JCT (Joint Contracts Tribunals) atau AIA (American Institute of Architects).

FIDIC (Federation Internasional Des Ingenieurs-Conseils) merupakan salah satu kontrak yang paling sering digunakan secara global dalam dunia konstruksi. FIDIC menyusun standar tipe kontrak kerja konstruksi untuk menyetarakan bentuk kontrak yang sudah digunakan. Pada tahun 1957, FIDIC menerbitkan tipe kontrak kerja konstruksi pertama yang kemudian kontrak ini digunakan sebagai acuan oleh berbagai organisasi di dunia.

Di Indonesia penggunaan jenis kontrak FIDIC sering digunakan untuk diadaptasi karena ketidaktersediaan standar baku kontrak selama ini. Penggunaan kontrak FIDIC sebagai standar pembuatan kontrak tidaklah mutlak namun dapat dimodifikasi dan disesuaikan sesuai peraturan negara setempat dan kebijakan pihak yang bersangkutan.

Untuk lebih dapat memahami jenis-jenis kontrak dan mengidentifikasi kontrak proyek konstruksi yang tepat diimplementasikan di Indonesia, maka penelitian ini dilakukan 
dengan tujuan untuk mengetahui jenis dokumen kontrak konstruksi yang digunakan menurut standar FIDIC khususnya proyek konstruksi di Sumatera Utara, untuk mengetahui hubungan antara standar dokumen kontrak FIDIC dengan standar UU No.2 Tahun $2017^{3}$ tentang jasa konstruksi dan untuk mengetahui pedoman kontrak konstruksi di Indonesia khususnya proyek konstruksi di Sumatera Utara.

\section{TINJAUAN PUSTAKA}

\section{KONTRAK KERJA KONSTRUKSI}

Berdasarkan pengertian kontrak kerja konstruksi yang ada pada Undang-Undang No.2 Tahun $2017^{3}$ maka, unsur-unsur yang terdapat di dalam suatu kontrak kerja konstruksi antara lain :

a) Adanya para pihak yaitu pengguna jasa dan penyedia jasa.

b) Adanya objek yang diperjanjikan yaitu konstruksi.

c) Adanya dokumen yang mengatur hubungan hukum antara pengguna jasa dan penyedia jasa.

Hubungan hukum antara pengguna jasa dan penyedia jasa yang muncul dari perjanjian dalam kontrak berada dalam ranah hukum perdata, khususnya hukum perjanjian. UU No.2 Tahun $2017^{3}$ tentang jasa konstruksi menempatkan asas kesetaraan antara pengguna jasa dan penyedia jasa. Dalam asas tersebut, pengguna jasa dan penyedia jasa memiliki kedudukan yang setera. Demi mendukung penyelenggaraan asas kesetaraan, UU No.2 Tahun $2017^{3}$ memberikan wewenang kepada pemerintah untuk mengembangkan dokumen kontrak standar khususnya untuk kontrak kerja konstruksi.

Menurut Putri (2020) ${ }^{1}$, beberapa syarat-syarat penting pada suatu kontrak meliputi defenisi dan interpretasi, perubaham-perubahan, pelimpahan kontrak, jumlah perkiraan, dokumen kontrak, perbaikan-perbaikan, kewajiban-kewajiban umum, resiko khusus, penangguhan pekerjaan, pembebasan dari pelaksanaan, pelaksanaan dan keterlambatan, penyelesaian perselisihan, tanggungjawab atas cacat dan kesalahan pengguna jasa. Sedangkan persyaratan khusus kontrak (condition of particular) FIDIC antara lain defenisi 
kata/istilah tertentu, bahasa dan hukum yang berlaku, prioritas dokumen, jaminan pelaksanaan, bonus penyelesaian, arbitrase dan kesalahan pengguna jasa/penyedia jasa.

\section{KONTRAK KONSTRUKSI FIDIC}

Pada tahun 1999, FIDIC menerbitkan format standar kontrak yaitu : Condition contract for construction (red book), Condition of contract for plant and design-build (yellow book), Condition of contract for turnkey project (silver book) dan Short form of contract (green book). Sedangkan dokumen kontrak terdiri atas perjanjian kontrak (contract agreement), surat penunjukkan (letter of acceptance/award), surat penawaran (for/letter of tender), kondisi kontrak (condition of contract), spesifikasi (specification), gambar (drawings), waktu pelaksanaan (schedules), lampiran untuk tender (appendix to tender), harga pekerjaan dan jadwal pekerjaan (bill of quality and dayword schedule) dan dokumen-dokumen lain yang termasuk di dalam contract agreement (Sarwono Hardjomuljadi, dkk., 2008) ${ }^{3}$.

Beberapa pihak yang terlibat dalam proyek konstruksi berdasarkan FIDIC yaitu pengguna jasa (pemilik) sebagai pemberi pekerjaan yang telah disahkan oleh hukum dan berhak membuat suatu kegiatan atau bentuk proyek konstruksi, kontraktor yang bertugas untuk melaksanakan pembangunan dan bertanggung jawab untuk seluruh pekerjaan dan kemajuan proyek sesuai dengan jadwal yang telah disepakati dalam kontrak, sub kontraktor yang terdiri atas sub kontraktor permanent dan sub kontraktor temporary serta engineer yang terdiri atas tenaga ahli teknik dan profesional lainnya yang memenuhi syarat kualifikasi yang kompeten untuk melaksanakan tugas dalam pekerjaan konstruksi.

\section{UNDANG-UNDANG NO. 2 TAHUN 2017}

Berdasarkan UU No. 2 Tahun $2017^{3}$ diketahui bahwa secara umum materi muatan dalam UU ini meliputi tanggungjawab dan kewenangan, usaha jasa konstruksi, penyelenggaraan usaha konstruksi, keamanan, keselamatan, kesehatan dan keberlanjutan konstruksi, tenaga kerja konstruksi, pembinaan, sistem informasi jasa konstruksi, partisipasi masyarakat, penyelesaian sengketa, sanksi administratif dan ketentuan peralihan. 
Dalam UU No. 2 Tahun $2017^{3}$, kontrak kerja konstruksi harus rumusan pekerjaan yang menguraikan dengan jelas dan rinci tentang lingkup kerja, nilai pekerjaan, harga satuan, lumsum dan batasan waktu pelaksanaan. Kontrak kerja konstruksi juga harus memuat cara pembayaran yang mengatur ketentuan tentang kewajiban pengguna jasa dalam melakukan pembayaran hasil layanan jasa konstruksi termasuk di dalamnya jaminan atas pembayaran. Selain itu, kontrak kerja konstruksi juga memuat mengenai hak dan kewajiban yang setara, memuat hak pengguna jasa untuk memperoleh hasil jasa konstruksi dan kewajibannya untuk memenuhi ketentuan yang diperjanjikan, serta hak penyedia jasa untuk memperoleh informasi dan imbalan jasa serta kewajibannya melaksanakan layanan jasa konstruksi. Kontrak kerja konstruksi juga berisikan masa pertanggungan, memuat tentang jangka waktu pelaksanaan dan pemeliharaan yang menjadi tanggung jawab penyedia jasa; kontrak kerja memuat mengenai kegagalan bangunan yaitu tentang ketentuan kejadian yang timbul di luar kemauan dan kemampuan para pihak yang menimbulkan kerugian bagi salah satu pihak.

\section{METODE PENELITIAN}

Metode yang digunakan dalam penelitian ini adalah berupa kajian literatur yang mengumpulkan data-data dari berbagai sumber tertulis yaitu berasal dari buku, arsip, majalah, artikel dan jurnal atau dokumen-dokumen yang relevan dengan permasalahan yang dikaji dalam penelitian ini. Pengambilan data dilakukan dengan cara penyebaran kuisioner kepada beberapa proyek konstruksi yang sedang berlangsung di Sumatera Utara.

\section{ANALISIS DAN HASIL}

Berdasarkan hasil dari pertanyaan yang diberikan kepada 8 (delapan) proyek konstruksi terhadap penelitian ini, maka hasil dari tabulasi data dijabarkan pada Tabel 1 berikut.

Tabel 1. Tabulasi pengelompokkan hasil kuisioner pada proyek konstruksi di Sumatera Utara

\begin{tabular}{|l|l|l|}
\hline No. & Item Penilaian & Hasil tabulasi penilaian responden \\
\hline
\end{tabular}




\begin{tabular}{|c|c|c|}
\hline 1. & Jenis kontrak & $\begin{array}{l}\text { a) } 6 \text { proyek = unit price } \\
\text { b) } 2 \text { proyek = lump sum }\end{array}$ \\
\hline 2. & Tanggung jawab pekerjaan & 8 proyek $=$ penyedia jasa \\
\hline 3. & Desain proyek & $\begin{array}{l}\text { a) } 7 \text { proyek }=\text { owner }+ \text { kontraktor } \\
\text { b) } 1 \text { proyek }=\text { owner }\end{array}$ \\
\hline 4. & Perhitungan jasa & $\begin{array}{l}\text { a) } 6 \text { proyek }=\text { biaya }+ \text { jasa } \\
\text { b) } 2 \text { proyek }=\text { biaya }+ \text { jasa pasti }\end{array}$ \\
\hline 5. & Sumber dana & $\begin{array}{l}\text { a) } 6 \text { proyek }=\text { pemerintah } \\
\text { b) } 2 \text { proyek }=\text { swasta } / \text { mandiri }\end{array}$ \\
\hline 6. & Sistem pembayaran & $\begin{array}{l}\text { a) } 6 \text { proyek }=\text { sesuai progres } \\
\text { b) } 1 \text { proyek }=\text { per bulan } \\
\text { c) } 1 \text { proyek }=\text { sesudah proyek selesai }\end{array}$ \\
\hline 7. & Golongan kontraktor & $\begin{array}{l}\text { a) } 6 \text { proyek }=\text { kontraktor besar }(\text { gred } 6 \& \text { gred } 7) \\
\text { b) } 2 \text { proyek }=\text { kontraktor sedang }(\text { gred } 5)\end{array}$ \\
\hline 8. & Hukum & 8 proyek $=$ hukum Indonesia \\
\hline 9. & Jenis asuransi & $\begin{array}{l}\text { a) } 7 \text { proyek }=\text { CAR }(\text { contractor all risk) } \\
\text { b) } 1 \text { proyek }=\text { asuransi lainnya }\end{array}$ \\
\hline 10. & Jenis keterlambatan & $\begin{array}{l}\text { a) } 4 \text { proyek }=1 \text { jenis keterlambatan (alam) } \\
\text { b) } 2 \text { proyek }=2 \text { jenis keterlambatan (kontraktor } \& \\
\text { alam) } \\
\text { c) } 2 \text { proyek }=4 \text { jenis keterlambatan (alam, } \\
\text { kontraktor, pengguna jasa dan berlapis) }\end{array}$ \\
\hline 11. & Uang muka & $\begin{array}{l}\text { a) } 1 \text { proyek }=15 \% \text { dari nilai kontrak } \\
\text { b) } 6 \text { proyek }=20 \% \text { dari nilai kontrak } \\
\text { c) } 1 \text { proyek }=25 \% \text { dari nilai kontrak }\end{array}$ \\
\hline 12. & Masa pemeliharaan & $\begin{array}{l}\text { a) } 3 \text { proyek }=\text { pemeliharaan } 6 \text { bulan } \\
\text { b) } 2 \text { proyek }=\text { pemeliharaan } 1 \text { tahun } \\
\text { c) } 1 \text { proyek }=\text { pemeliharaan } 2 \text { tahun } \\
\text { d) } 2 \text { proyek }=\text { pemeliharaan } 3 \text { tahun }\end{array}$ \\
\hline 13. & $\begin{array}{l}\text { Nilai untuk masa } \\
\text { pemeliharaan }\end{array}$ & 8 proyek $=5 \%$ dari nilai kontrak \\
\hline
\end{tabular}

Sumber : Hasil analisis (2020)

Tabel 3. Hasil jawaban terhadap item pada dokumen FIDIC

Sedangkan berdasarkan klasifikasi 8 (delapan) proyek konstruksi yang di data terhadap kontrak standar FIDIC adalah seperti yang dijabarkan pada Tabel 2 berikut.

Tabel 2. Klasifikasi jenis kontrak FIDIC terhadap proyek konstruksi

\begin{tabular}{|c|c|c|}
\hline No. & \multicolumn{1}{|c|}{ Proyek konstruksi } & Jenis kontrak FIDIC \\
\hline 1. & $\begin{array}{l}\text { Proyek pembangunan gedung sekolah di Kota } \\
\text { Medan, Kab. Samosir, Kab. Maidailing Natal dan }\end{array}$ & \\
\hline
\end{tabular}




\begin{tabular}{|c|l|l|}
\hline & Kabupaten Tapanulis Tengah & \\
\hline 2. & $\begin{array}{l}\text { Proyek pelebaran jembatan Sei Paret Busuk Kota } \\
\text { Medan }\end{array}$ & FIDIC Silver Book \\
\hline 3. & $\begin{array}{l}\text { Proyek penggantian jembatan Aek Hapilis } \\
\text { Pangaloan dan jembatan Aek Sioto, Kab. Samosir }\end{array}$ & FIDIC Silver Book \\
\hline 4. & Proyek pelebaran jembatan Samosir, Kab. Samosir & FIDIC Silver Book \\
\hline 5. & $\begin{array}{l}\text { Proyek pelebaran Alur Tanoo Ponggol, Kab. } \\
\text { Samosir }\end{array}$ & FIDIC Red Book \\
\hline 6. & $\begin{array}{l}\text { Proyek pembangunan penyeberangan Pelabuhan } \\
\text { Simanindo, Kab. Samosir }\end{array}$ & FIDIC Red Book \\
\hline 7. & $\begin{array}{l}\text { Proyek pembangunan Jalan Tol ruas Tebing Tinggi } \\
\text {-Inderapura Seksi 1 Tebing Tinggi }\end{array}$ & FIDIC Red Book \\
\hline 8. & $\begin{array}{l}\text { Proyek pembangunan Jalan Tol ruas Kuala Tanjung } \\
\text {-Inderapura Seksi 2 Tebing Tinggi }\end{array}$ & FIDIC Red Book \\
\hline
\end{tabular}

Sumber : Hasil analisis (2020)

Perbandingan dokumen kontrak FIDIC dengan UU No.2 Tahun $2017^{3}$ digambarkan pada Tabel 3 berikut.

Tabel 3. Tabulasi perbandingan kontrak FIDIC dengan UU No.2 tahun 2017

\begin{tabular}{|c|c|c|}
\hline Item & FIDIC & UU No.2 Tahun 2017 \\
\hline $\begin{array}{l}\text { Jenis kontrak yang } \\
\text { digunakan dalam } \\
\text { proyek }\end{array}$ & $\begin{array}{l}\text { a) Red book (lump sum } \\
\text { contract) } \\
\text { b) Yellow book (lump sum } \\
\text { contract) } \\
\text { c) Silver book (lump sum } \\
\text { contract) } \\
\text { d) Green book (lump sum } \\
\text { contract) } \\
\text { e) Pink book (lump sum } \\
\text { contract) } \\
\text { f) Gold book (lump sum } \\
\text { contract) }\end{array}$ & $\begin{array}{l}\text { a) Lump sum } \\
\text { b) Unit price contract } \\
\text { c) Cost plus contract }\end{array}$ \\
\hline $\begin{array}{l}\text { Tanggung jawab } \\
\text { seluruh pekerjaan }\end{array}$ & $\begin{array}{l}\text { a) Penyedia jasa } \\
\text { b) Pengguna jasa }\end{array}$ & $\begin{array}{l}\text { a) Penyedia jasa } \\
\text { b) Pengguna jasa }\end{array}$ \\
\hline Desain proyek & $\begin{array}{l}\text { a) Penyedia jasa } \\
\text { b) Pengguna jasa }\end{array}$ & $\begin{array}{l}\text { a) Penyedia jasa } \\
\text { b) Pengguna jasa }\end{array}$ \\
\hline
\end{tabular}




\begin{tabular}{|c|c|c|}
\hline $\begin{array}{l}\text { Aspek perhitungan } \\
\text { jasa dalam proyek }\end{array}$ & Tidak disebutkan & $\begin{array}{l}\text { a) Biaya tanpa jasa } \\
\text { b) Biaya ditambah jasa } \\
\text { c) Biaya ditambah jasa pasti }\end{array}$ \\
\hline $\begin{array}{l}\text { Jaminan dalam } \\
\text { kontrak }\end{array}$ & $\begin{array}{l}\text { a) Jaminan pelaksanaan } \\
\text { b) Jaminan kualitas }\end{array}$ & $\begin{array}{l}\text { a) Jaminan uang muka } \\
\text { b) Jaminan pelaksanaan } \\
\text { c) Jaminan perawatan atas } \\
\text { cacat } \\
\text { d) Jaminan pembayaran }\end{array}$ \\
\hline $\begin{array}{l}\text { Sumber dana } \\
\text { proyek }\end{array}$ & $\begin{array}{l}\text { a) MDB (bank pembangunan } \\
\text { multilateral) } \\
\text { b) Swasta/personal/saham }\end{array}$ & $\begin{array}{l}\text { a) APBN (Anggaran } \\
\text { Pendapatan dan Belanja } \\
\text { Daerah) } \\
\text { b) Swasta/personal } \\
\end{array}$ \\
\hline Sistem pembayaran & $\begin{array}{l}\text { a) Pembayaran bulanan } \\
\text { b) Pembayaran berdasarkan } \\
\text { progres } \\
\text { c) Pembayaran setelah proyek } \\
\text { selesai }\end{array}$ & $\begin{array}{l}\text { a) Pembayaran bulanan } \\
\text { b) Pembayaran berdasarkan } \\
\text { progres } \\
\text { c) Pembayaran setelah proyek } \\
\text { selesai }\end{array}$ \\
\hline $\begin{array}{l}\text { Jenis } \\
\text { keterlambatan }\end{array}$ & $\begin{array}{l}\text { a) Keterlambatan yang } \\
\text { disebabkan oleh kontraktor } \\
\text { b) Keterlambatan yang } \\
\text { disebabkan alam atau } \\
\text { bersifat alamiah } \\
\text { c) Keterlambatan yang } \\
\text { disebabkan pengguna jasa }\end{array}$ & $\begin{array}{l}\text { a) Keterlambatan yang } \\
\text { disebabkan oleh kontraktor } \\
\text { b) Keterlambatan yang } \\
\text { disebabkan alam atau } \\
\text { bersifat alamiah } \\
\text { c) Keterlambatan yang } \\
\text { disebabkan pengguna jasa } \\
\text { d) Keterlambatan berlapis } \\
\text { (disebabkan pengguna jasa } \\
\text { dan penyedia jasa) }\end{array}$ \\
\hline $\begin{array}{l}\text { Golongan } \\
\text { kontraktor dalam } \\
\text { proyek }\end{array}$ & Tidak disebutkan & \begin{tabular}{|l|} 
a) Besar \\
b) Sedang \\
c) Kecil \\
\end{tabular} \\
\hline $\begin{array}{l}\text { Hukum yang } \\
\text { digunakan }\end{array}$ & Hukum Internasional & Hukum Indonesia \\
\hline $\begin{array}{l}\text { Pihak yang } \\
\text { membayar seluruh } \\
\text { pajak, bea dan } \\
\text { seluruh biaya } \\
\text { berdasarkan } \\
\text { kontrak }\end{array}$ & Kontraktor & Pengguna jasa \\
\hline Masa pemeliharaan & Tidak disebutkan & $\begin{array}{l}\text { a) Paling singkat } 3 \text { bulan untuk } \\
\text { pekerjaan semi permanen } \\
\text { b) Paling singkat } 6 \text { bulan untuk } \\
\text { pekerjaan permanen }\end{array}$ \\
\hline
\end{tabular}




\begin{tabular}{|l|l|l|}
\hline $\begin{array}{l}\text { Nilai untuk masa } \\
\text { pemeliharaan }\end{array}$ & Tidak disebutkan & $5 \%$ \\
\hline
\end{tabular}

Sumber : Hasil analisis (2020)

Berdasarkan perbedaan antara dokumen kontrak FIDIC dan UU No.2 Tahun $2017^{3}$ yang telah dijabarkan sebelumnya maka dapat disimpulkan bahwa $75 \%$ proyek konstruksi di Sumatera Utara berpedomani UU No.2 Tahun $2017^{3}$ dan $75 \%$ proyek konstruksi berpedomani dokumen FIDIC dengan persentase sebesar 25\%. Dan pedoman serta landasan dalam berkontrak pada proyek yang ada di Sumatera Utara mengacu pada UU No. 2 Tahun $2017^{3}$ dan menggunakan jenis kontrak unit price (harga satuan) karena dianggap lebih memberikan kepastian terhadap pembayaran.

\section{KESIMPULAN}

Berdasarkan analisis dan pembahasan yang telah dilakukan terhadap temuan data di lapangan ataupun berdasarkan kajian literatur, maka kesimpulan yang dapat diambil adalah dokumen kontrak konstruksi yang digunakan menurut standar FIDIC terhadap proyek konstruksi di Sumatera Utara yaitu menurut dokumen FIDIC dengan hasil analisa terbanyak yaitu dari total 8 proyek konstruksi ditemukan 4 proyek konstruksi menggunakan FIDIC Red book, 3 proyek konstruki menggunakan FIDIC Silver book dan 1 proyek konstruksi menggunakan FIDIC Green book. Kontrak yang paling sesuai terhadap data kuisioner yaitu UU No.2 Tahun $2017^{3}$ dengan angka persentase $75 \%$ dan FIDIC dengan persentase $25 \%$.

\section{DAFTAR PUSTAKA}

Cynthia, H. P., (2020). Analisis Kontrak Konstruksi di Indonesia. Tugas Akhir Program Studi Teknik Sipil Universitas Pelita Harapan. Universitas Pelita Harapan.

Hardjomuljadi, S., Abdukadir, A., dkk. (2008). Persyaratan Kontrak Untuk Pelaksanaan Konstruksi. Jakarta: Lembaga Pengembangan Jasa Konstruksi, Ikatan Nasional Konsultan Indonesia, Federation Internationale Des Ingenieurs Conselts. 
Jurnal Visi Eksakta (JVIEKS)

Vol.2, No.2, Juli 2021, pp. 205-214

https://ejournal.uhn.ac.id/index.php/eksakta

Undang-Undang Republik Indonesia Nomor 02 Tahun 2017. Jasa Kontruksi. 12 Januari 2017. Lembaran Negara Republik Indonesia Tahun 2017 Nomor 11. Jakarta. 